\title{
RESTORATIVE JUSTICE HAKIM TERHADAP ANAK YANG BERKONFLIK DENGAN HUKUM DI PENGADILAN NEGERI LHOKSEUMAWE*
}

\author{
Sumiadi $^{* *}$, Laila M. Rasyid ${ }^{* * *}$, dan Romi Asmara ${ }^{* * * *}$ \\ Departemen Hukum Pidana, Fakultas Hukum Universitas Malikussaleh, Kota Lhokseumawe \\ Kampus Bukit Indah, Jalan Jawa Blang Pulo, Kecamatan Muara Satu Lhokseumawe \\ Nanggroe Aceh Darussalam, 24300
}

\begin{abstract}
Children are part of the younger generation as one of the human resources as potential successors in the future. Violation of law that occurs in the community not only done by adults but also by children, the implementation of the sentence would have been very different from adults. In children should more be rehabilitation rather than punitive. The results showed that judge who examine and rule on cases of children in conflict with the law in District Court Lhokseumawe still think positivistic/legalistic where decisions are decided by the judges commonly used approach based on the criminal justice system.
\end{abstract}

Keywords: judge perspective, children, in conflict with law, district court.

\section{Intisari}

Anak adalah bagian dari generasi muda sebagai salah satu sumber daya manusia yang merupakan potensi dan penerus cita-cita perjuangan bangsa di masa yang akan datang. Pelanggaran hukum yang terjadi di masyarakat tidak saja dilakukan oleh orang dewasa akan tetapi juga oleh anak-anak, pelaksanaan hukumannya tentulah sangat berbeda dengan orang dewasa. Pada anak-anak haruslah lebih bersifat rehabilitasi daripada menghukum. Hasil penelitian menunjukkan bahwa seorang hakim yang memeriksa dan memutus perkara anak yang berkonflik dengan hukum di Pengadilan Negeri Lhokseumawe masih beraliran positivistik/legalistik dimana putusan yang diputus oleh hakim yang paling umum digunakan adalah pendekatan yang berpatokan pada sistem peradilan pidana semata.

Kata Kunci: perspektif hakim, anak, berkonflik dengan hukum, pengadilan negeri.

\section{Pokok Muatan}

A. Latar Belakang Masalah ....................................................................................................... 44

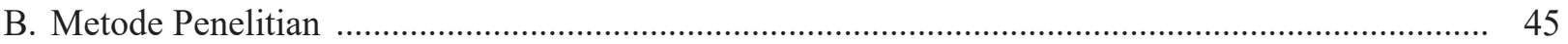

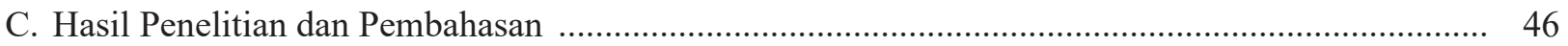

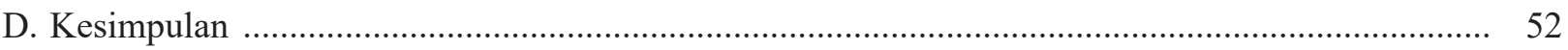

Penelitian Hibah Bersaing DP2M DIKTI No. 33/UN45.7/PL/III/2015..

Alamat korespondensi: sumiadi7@gmail.com.

* Alamat korespondesi : laila077@gmail.com.

***** Alamat Korespondensi : romi_asmara@yahoo.com. 


\section{A. Latar Belakang Masalah}

Anak merupakan amanah sekaligus karunia Tuhan Yang Maha Esa, bahkan anak dianggap sebagai harta kekayaan yang paling berharga dibandingkan kekayaan harta benda lainnya. Anak sebagai amanah Tuhan harus senantiasa dijaga dan dilindungi karena dalam diri anak melekat harkat, martabat, dan hak-hak sebagai manusia yang harus dijunjung tinggi. Anak menpunyai kedudukan yang sangat strategis dalam kehidupan berbangsa dan bernegara. ${ }^{1}$ dan Hak asasi anak merupakan bagian dari hak asasi manusia yang termuat dalam UndangUndang Dasar 1945 dan Konvensi Perserikatan Bangsa-Bangsa tentang Hak-Hak Anak. ${ }^{2}$

Anak adalah bagian dari generasi muda sebagai salah satu sumber daya manusia yang merupakan potensi dan penerus cita-cita perjuangan bangsa di masa yang akan datang, yang memiliki peran strategis dan mempunyai ciri dan sifat khusus, memerlukan pembinaan dan perlindungan dalam rangka menjamin pertumbuhan dan perkembangan fisik, mental, dan sosial secara seimbang. ${ }^{3}$

Seiring perjalanan waktu dalam kenyataannya dewasa ini pelanggaran hukum yang terdapat di dalam masyarakat tidak saja dilakukan oleh orang dewasa, tetapi juga dilakukan oleh anak-anak. Pelaksanaan hukuman akibat dari tindak pidana yang dilakukan oleh seorang anak tentulah sangat berbeda dengan orang yang telah dewasa. Tindakan koreksi terhadap anak delinkuen haruslah lebih bersifat rehabilitasi daripada bersifat menghukum. ${ }^{4}$

Anak sebagai pelaku tindak pidana sering dijumpai dalam kehidupan sehari-hari. Perilaku anak melakukan tindak pidana sering dikategorikan sebagai anak nakal atau melakukan pelanggaran hukum. Anak-anak dalam kondisi demikian disebut dengan anak yang berkonflik dengan hukum (Children in conflict with the law). ${ }^{5}$ Anak yang berkonflik dengan hukum dapat didefenisikan anak yang disangka, dituduh atau diakui sebagai telah melanggar undang-undang hukum pidana.

Pada dasarnya anak mempunyai hak yang bersifat asasi, sebagaimana yang dimiliki orang dewasa, yaitu hak asasi manusia (HAM), namun yang terjadi adalah anak-anak pelaku tindak pidana tidak mendapat perlindungan hukum sebagaimana mestinya dalam suatu proses hukum. Dan tak jarang kekerasan masih mewarnai dalam proses pemeriksaan perkara anak-anak sebagai pelaku tindak pidana, baik pada tahap penyidikan, penuntutan, maupun pada saat sidang pemeriksaan di muka pengadilan ${ }^{6}$ bahkan $100 \%$ vonis hakim berupa hukuman penjara. ${ }^{7}$

Dalam perkembangannya banyak faktor yang menyebabkan seorang anak berkonflik dengan hukum, baik faktor internal anak itu sendiri maupun eksternal nya yang antara lain faktor keluarga, sekolah juga faktor lingkungan sekitar yang tidak selalu menguntungkan bagi pendidikan dan perkembangan anak. Beberapa konflik yang menyebabkan anak berkonflik dengan hukum membawa mereka ke dalam kondisi yang merugikan anak-anak, padahal tingginya kasus anak yang berakhir di penjara, sepertinya tidak sebanding dengan keberhasilan model pemenjaraan dalam menekan tingkat kriminalitas pada anak.

Menurut Franc Loppy, Putusan hakim itu mahkota, mencerminkan segalanya bagi hakim, tanggung jawabnya, kejujurannya, kearifannya, kecerdasannya, kreatifitasnya, keilmuannya,

Romi Asmara, et al., "Kejahatan Kesusilaan Terhadap Ana (Suatu Tinjauan Perlindungan Hukum Terhadap Anak Perempuan Korban Kejahatan Kesusilaan Di Kota Lhokseumawe)", Jurnal Pasai, Vol. II, No. 2, September, 2008, hlm. 70

Lukman Hakim dan Nainggolan, "Masalah Perlindungan Hukum Terhadap Anak", Jurnal Equality, Vol. 10, No. 2, Agustus 2006 , hlm. 90. Lihat juga Dewi Nurul Musjtari, "Memberikan Hak Memilih Agama Sebagai Upaya Perlindungan Anak", Jurnal Konstitusi, Vol. 3, No. 2, Mei 2006, hlm.25.

Ibid.

W.A Gerungan, 1996, Psikologi Sosial, Eresco, Bandung, hlm. 215

Ika Saimima, "Perlindungan Terhadap Anak Yang Berkonflik Dengan Hukum", Jurnal Kajian Ilmiah Lembaga Penelitian Ubhara Jaya, Vol. 9, No. 3, 2008, hlm.940

Mahmud Mulyadi, "Perlindungan Terhadap Anak Yang Berkonflik Dengan Hukum: Upaya Menggeser Keadilan Retributif Menuju Keadilan Restoratif”, Jurnal Equality, Vol. 13, No. 1, Februari, 2008, hlm. 83.

Yanuar Farida Wimayanti, "Model Penanganan Anak Berkonflik Hukum”, Jurnal Informasi, Vol. 12, No. 03, 2007, hlm. 41. 
moralitasnya, ketulusannya, keshalehannya dan lain sebagainya. ${ }^{8}$ Putusan merupakan tahap akhir dan merupakan tujuan akhir dari setiap pemeriksaan perkara. Penjatuhan putusan inilah yang menentukan salah atau tidaknya terdakwa anak nakal. Dalam hal penjatuhan putusan dilakukan hakim tunggal tentulah musyawarah tidak diperlukan akan tetapi dalam hal susunan hakim majelis musyawarah merupakan hal yang wajib.

Menurut pernyataan para hakim di Pengadilan Negeri Pati, putusan merupakan mahkota dari seorang hakim, artinya dari putusannyalah sebenarnya diketahui bagaimana sesungguhnya seorang hakim memeriksa, mengadili, memutus suatu perkara. Putusan bukanlah kesimpulan karena putusan didasarkan atas pertimbanganpertimbangan yang mendalam atas setiap perkara. Pertimbangan ini diperoleh dari fakta-fakta yang terungkap di persidangan. Suatu putusan yang memuat sanksi didahului oleh pernyataan terbuktinya seseorang secara sah dan menyakinkan bersalah melakukan suatu tindak pidana tertentu.

Berkaitan dengan sanksi pada anak nakal dapat berupa pidana maupun tindakan sebagaimana ditentukan dalam UU No. 3 Tahun 1997. Dasar pertimbangan-pertimbangan mendalam yang dilakukan hakim dalam rangka penjatuhan sanksi terhadap anak nakal dapat dikategorikan dalam beberapa faktor yaitu:

1. Faktor Yuridis

2. Faktor Non Yuridis
a. Faktor Filosofis
b. Faktor Sosiologis
c. Faktor Psikologis
d. Faktor Kriminologis

Meskipun faktor yuridis dan faktor non yuridis merupakan dasar penjatuhan sanksi terhadap anak nakal, akan tetapi kenyataannya pidana perampasan kemerdekaan tetap menjadi sentral dalam posisi stelsel sanksi pidana, kebanyakan hakim cenderung menjatuhkan pidana penjara kepada anak, ${ }^{9}$ daripada memilih alternatif hukuman lainnya sebagaimana yang diatur oleh undang-undang. Para hakim masih menganut filosofi pemidanaan yang bersifat retributif (pembalasan) ketimbang pemidanaan yang bersifat restorative dengan tujuan untuk memperbaiki. ${ }^{10}$

Lhokseumawe sebagai salah satu Kotamadya yang ada di Provinsi Aceh, karena terdiri dari 4 Kecamatan ternyata juga tidak terlepas dari persoalan anak yang berkonflik dengan hukum dengan berbagai jenisnya, Pada 4 tahun terakhir (2010-2014) terdapat angka yang cukup banyak yang melibatkan anak sebagai terdakwa, antara lain pada perkara pencurian, kecelakaan lalu lintas, narkotika, dan perbuatan cabul. Angka itu menunjukkan bahwa terhadap anak yang berkonflik dengan hukum kebanyakan dijatuhkan putusan pidana penjara yang tentu saja bertentangan dengan UU Nomor 39 Tahun 1999 Tentang Hak Asasi Manusia dimana dirumuskan bahwa terhadap anak yang melakukan kejahatan, penjatuhan pidana berupa perampasan kemerdekaan adalah sebagai upaya terakhir.

Menarik untuk diteliti lebih lanjut mengenai perspektif hakim di Pengadilan Negeri Lhokseumawe untuk didapat sebuah hasil yang dapat digunakan bagi para hakim anak di daerah lainnya. Berdasarkan latar belakang maka yang menjadi perumusan masalah adalah bagaimana perspektif Restorative Justice hakim dalam membuat putusan mengenai anak yang sedang berkonflik dengan hukum di Pengadilan Negeri Lhokseumawe.

\section{B. Metode Penelitian}

Penelitian ini dilakukan di Kota Lhokseumawe karena lokasi ini salah satu tempat yang juga ada anak yang berkonflik dengan hukum.

Fauzan, "Rekonstruksi Teori Pemerataan Keadilan", Varia Peradilan, Vol. XXIII, Februari, 2008, hlm. 37.

Nashriana, 2009, Pertimbangan Hakim Dalam Menjatuhkan Putusan Pidana Penjara Terhadap Anak Pelaku Penyalahgunaan Narkoba, Tesis, FH Universitas Sriwijaya, Palembang, hlm.1. Lihat juga Surastini Fitriasih, "Analisa Pertimbangan hakim Dalam menjatuhkan Hukuman Bagi Terpidana Anak (Studi Awal Tentang Putusan Hakim Anak)”, http://lontar.ui.ac.id/opac/ui/detail.jsp, diakses Tanggal 1 Maret 2015.

10 Fitriasih, Sulastini, Analisa Pertimbangan Hakim Dalam Menjatuhkan Hukuman Bagi Terpidana Anak (Studi Awal Tentang Putusan Hakim Anak), Laporan Penelitian Universitas Indonesia, Depok, hlm.1. 
Data-data yang dikumpulkan dalam penelitian ini menurut jenisnya yaitu data primer dan data sekunder. Dengan jenis pendekatan secara kualitatif yang dipilih karena informasi dan data melalui penelitian ini banyak dalam bentuk teks dan sejumlah studi kasus. Instrumen yang digunakan adalah studi dokumentasi untuk menemukan kerangka konsepsional, azas peraturan perundangundangan. Observasi yang dilakukan dalam penelitian ini dengan melakukan pengamatan dalam persidangan anak, Adapun wawancara dilakukan secara mendalam untuk mengetahui pengawasan terhadap hakim yang sudah berjalan selama ini baik oleh pemerintah.

Data Sekunder terdiri dari bahan hukum ${ }^{11}$ yang dalam penelitian ini didapat dengan penelusuran sejumlah literatur yang berhubungan dengan pertimbangan dalam putusan hakim. Juga dengan meneliti sejumlah peraturan perundangundangan yang berhubungan dengan anak dan peradilan anak, dari sistem hukum positif Indonesia.

Data primer dalam penelitian ini diperoleh melalui penelitian lapangan untuk mengetahui apakah peraturan perundang-undangan yang mengatur mengenai peradilan anak dan pengawasan hakim anak yang sudah berlaku dengan melakukan observasi dan wawancara dengan nara sumber yang telah ditentukan.

Pengolahan data dalam penelitian tidak terpisahkan dari pengumpulan data. Data primer yang telah didapatkan diolah dengan cara mengkategori antara data yang satu dengan lainnya dengan pengkategorian data demikian dapat dikelompokkan data berdasarkan masalah penelitian. Data yang sudah terkumpul kemudian diolah melalui tahap pemeriksaan (editing), penandaan (coding), penyusunan (reconstructing), dan sistematisasi (systematizing) berdasarkan urutan pokok bahasan dan subpokok bahasan.

\section{Hasil Penelitian dan Pembahasan}

Hakim anak diangkat berdasarkan surat keputusan Mahkamah Agung atas usul Ketua Pengadilan Negeri yang bersangkutan melalui Ketua Pengadilan Tinggi. Berdasarkan Pasal 43 ayat (2) UU No.11 Tahun 2012 tentang Sistem Peradilan Pidana Anak, hakim anak harus mempunyai kualifikasi: ${ }^{12}$ a) telah berpengalaman sebagai hakim di pengadilan dalam lingkungan peradilan umum. b) mempunyai minat, perhatian, dedikasi, dan memahami masalah anak; c) telah mengikuti pelatihan teknis tentang peradilan anak. Berkaitan dengan pasal tersebut, perlu dibuat peraturan pelaksanaan yang mengatur tentang syarat-syarat menjadi hakim anak. Seperti tentang pengalaman menjadi hakim, perlu dijabarkan pengalaman dalam hal penanganan perkara anak. Hal ini didasarkan pertimbangan bahwa hakim anak merupakan hakim khusus yang memiliki keahlian khusus dalam rangka perlindungan anak. Hakim anak disamping berpendidikan sarjana hukum ditambah dengan pengetahuan tentang psikologi, psikiatri, sosiologi, sosial pedagogi dan andragogi; mencintai anak, dapat menyelami jiwa anak, berkarakter ingin ikut membina dan membantu terutama anak yang dalam kesulitan.

Sesungguhnya, disamping syarat-syarat yang ditentukan di atas, perlu ditambah persyaratan umur atau lama bertugas di Pengadilan untuk diangkat menjadi Hakim Anak. Yang cocok menjadi hakim anak adalah para hakim yang telah berumur 45 (empat puluh lima) tahun ke atas dan yang sudah berkeluarga, atau sudah yang berkeluarga yang telah bertugas sebagai hakim minimal 15 (lima belas) tahun.Hakim tersebutlebihmempunyai pengalaman/ wawasan yang luas, yang diharapkan lebih arif dan bijaksana dalam menangani perkara pidana anak. Hakim anak sebaiknya yang mempunyai kualifikasi setingkat Strata Dua/Magister (S-2) bahkan Strata Tiga/Doktor(S-3). Hakim yang memiliki kualifikasi

\footnotetext{
1 Soekanto Soerjono, Sri Mamudji, 2003, Penelitian Hukum Normatif, SuatuTinjauan Singkat, Ed.1,Cet 6,Raja Grafindo Persada, Jakarta, hlm. 13.

12. Pasal 43 ayat (2) Undang-Undang Nomor 11 Tahun 2012 tentang Sistem Peradilan Pidana Anak (Lembaran Negara Republik Indonesia Tahun 2012 Nomor 153, Tambahan Lembaran Negara Republik Indonesia Nomor 5332).
} 
tersebut, diharapkan dapat menganalisis segala hal yang berkaitan dengan masalah anak, dan dapat memprediksi serta mampu mengambil tindakan yang akurat berkaitan dengan perkara pidana anak.

Kemampuan memprediksi dan menganalis dimiliki oleh hakim tersebut dengan pendidikan yang diperoleh, terutama atau atas pengetahuan Filsafat Hukum. Apabila para penegak hukum telah dididik secara khusus untuk mengalami perkara pidana anak, maka perlindungan anak dapat diwujudkan, karena benar-benar dapat mehamami anak. Dalam menangani kenakalan anak, yang paling mendasar adalah memahami keadaan jiwa anak sebelum menjatuhkan pidana maupun keadaan jiwa anak setelah putusan dijatuhkan. Dalam hal ini psikologi kriminil/psikiatri sebagai salah satu cabang dari psikologi mempunyai peranan yang sangat penting untuk memahami keadaan jiwa anak. Psikologi kriminal/psikiatriberupaya mencari sebab kejahatan, cara-cara pencegahannya baik preventif maupun represif serta usaha-usaha perbaikan secara definitif perbuatan yang menyimpang (kenakalan) dengan cara-cara pendekatan psikologi.

Dalam praktik, pemahaman para hakim tentang peradilan anak sebagaimana diatur dalam UU No. 11 Tahun 2012, masih belum tepat. Seperti pemahaman tentang pengertian anak, banyak para hakim masih memahami bahwa pengertian anak adalah pengertian anak menurut ketentuan Pasal 45 KUHP, padahal pasal tersebut tidak berlaku lagi dengan berlakunya UU No. 3 Tahun 1997 yang merupakan UU peradilan anak sebelum UU No. 11 Tahun 2012. Pemahaman hakim tentang batasan umur anak kenyataannya belum tepat. Ada yang memahami bahwa atas umur anak adalah 16 (enam belas) tahun yang ke bawah, ada pula yang memahami anak adalah mereka yang berumur 18 (delapan belas) tahun ke bawah. Selain itu, pemahaman para hakim tentang perlindungan anak kurang tepat, dan mereka jarang bahkan tidak pernah mengikuti lokakarya atau penataran tentang perlindungan anak. Hal ini mempengaruhi penanganan perkara pidana anak yakni hakim tidak mampu memprediksi dan menganalisis kemungkinan yang terjadi diambil suatu keputusan tertentu.

Mahkamah Agung RI sebagai badan tertinggi pelaksanaan kekuasan kehakiman yang membawahi 4 (empat) badan peradilan dibawahnya, yaitu peradilan umum, peradilan agama, peradilan militer, dan peradilan tata usaha negara, telah menentukan bahwa putusan hakim harus mempertimbangkan segala aspek yang bersifat yuridis, filosofis, dan sosiologis, sehingga keadilan yang ingin dicapai, diwujudkan, dan dipertanggung jawabkan dalam putusan hakim adalah keadilan yang berorientasi pada keadilan hukum (legal justice), keadilan moral (moral justice), dan keadilan masyarakat (social justice).

Aspek yuridis merupakan aspek yang pertama dan utama dengan berpatokan kepada undangundang yang berlaku. Hakim sebagai aplikator undang-undang, harus memahami undang-undang dengan mencari undang-undang yang berkaitan dengan perkara yang sedang dihadapi. Hakim harus menilai apakah undang-undang tersebut harus adil, ada kemanfaatannya, atau memberikan kepastian hukum jika ditegakkan, sebab salah satu tujuan hukum itu unsurnya adalah menciptakan keadilan.

Mengenai aspek filosofis, merupakan aspek yang berintikan kepada kebenaran dan keadilan, sedangkan sosiologis, mempertimbangkan tata nilai budaya yang hidup dalam masyarakat. Aspek filosofis dan sosiologis, penerapannya sangat memerlukan pengalaman dan pengetahuan yang luas serta kebijaksanaan yang mampu mengikuti nilai-nilai dalam masyarakat yang terabaikan. Jelas penerapannya sangat sulit sebab tidak mengikuti asas legalitas dan tidak terikat pada sistem. Pencantuman ketiga unsur tersebut tidak lain agar putusan dianggap adil dan diterima masyarakat. Keadilan hukum (legal justice), adalah keadilan berdasarkan hukum dan perundang-undangan. Dalam arti hakim hanya memutuskan perkara hanya berdasarkan hukum positif dan peraturan perundang-undangan. Keadilan seperti ini keadilan menurut penganut aliran legalistis positivisme. Dalam menegakkan keadilan ini hakim atau pengadilan hanya sebagai 
pelaksana undang-undang belaka, hakim tidak perlu mencari sumber-sumber hukum di luar dari hukum tertulis dan hakim hanya dipandang menerapkan undang-undang pada perkara-perkara konkret rasional belaka. Dengan kata lain, hakim sebagai corong atau mulut undang-undang.

Dalam perspektif peradilan anak, subsistim dalam sistim peradilan anak mempunyai kekhususan, dimana terhadap anak sebagai suatu kajian hukum yang khusus, membutuhkan aparataparat yang secara khusus diberi wewenang untuk menyelenggarakan proses peradilan pidana terhadap anak yang berhadapan dengan hukum. Secara garis besar, aparat penegak hukum dalam sistem peradilan pidana bagi anak yang melakukan kenakalan sama dengan Sistem Peradilan Pidana yang berlaku bagi orang dewasa (ada Polisi, Jaksa Penuntut Umum, Hakim pemutus perkara, dan Lembaga Permasyarakatan), namun bagi anak ada kekhususan-kekhususan yang dipersyarakatkan bagi aparat penegak tersebut. Yang paling berbeda bahwa dalam proses peradilan anak diperlukan lembaga khusus yang disebut tugas pemasyarakatan.

$$
\text { Pengadilan Negeri Klas I B Kota }
$$
Lhokseeumawe adalah salah satu Pengadilan Negeri yang ada di Aceh yang telah memiliki beberapa hakim yang khusus menangani masalah anak yang berkonflik dengan hukum. Dari 5 tahun terakhir putusan yang telah dibaca dan dianalisis kebanyakan bentuk penghukuman yang diberikan adalah bentuk hukuman pidana berupa penjara kepada anak.

Pada wilayah hukum Pengadilan Negeri Lhokseumawe pada tahun 2010 terdapat 9 perkara yang pelakunya adalah anak yang berkonflik dengan hukum. Pada Tahun 2011 terdapat 14 perkara dan pada tahun 2012 terdapat 16 perkara. Tahun 2013 terdapat 7 perkara dan tahun 2014 sampai dengan Juni 10 perkara adalah perkara anak. Putusan pengadilan terhadap anak yang berkonflik dengan hukum diatas tercantum pada tabel di bawah ini.

Tabel 1.

Data Perkara Anak Di Pengadilan Negeri Lhokseumawe

\begin{tabular}{llll}
\hline No & Tahun & Jumlah Perkara & Jenis Hukuman \\
\hline 1 & 2010 & 9 Putusan & Penjara \\
2 & 2011 & 14 Putusan & 12 Penjara dan 2 Dikembalikan Ke Orang Tua \\
3 & 2012 & 16 Putusan & 11 Penjara, 1 Bebas dan 4 Dikembalikan Ke Orang Tua \\
4 & 2013 & 7 Putusan & 7 Penjara \\
5 & 2014 & 10 Putusan & 9 Penjara dan 1 dikembalikan Pada Orang tuan \\
\hline
\end{tabular}

Sumber: Putusan PN Lhokseumawe Tahun 2010-2014.

Dari seluruh putusan yang dijatuhkan oleh Hakim, menunjukkan bahwa hampir sama seperti pada Hakim di Pengadilan Negeri Lain, sikap Hakim pemutus perkara kental atau dipengaruhi oleh alam fikiran positivis/legalistik. ${ }^{13}$ Artinya suatu hukum baru dinyatakan sebagai hukum apabila terumus dalam undang-undang, itulah yang diterapkan, tidak terkecuali bagi anak-anak pelaku penyalahgunaan narkoba. Putusan hakim yang sebagian bersifat kumulatif stelsel (dengan mengancamkan pidana penjara yang dikumulatifkan dengan pidana denda), juga merupakan masalah. Hal ini menunjukkan bahwa hakim kurang memiliki rasa keadilan dan kepatutan walaupun ada juga putusan yang membebaskan anak dari ancaman hukuman. Selain itu, putusan pidana penjara yang dijatuhkan juga

13 Filsafat atau Aliran Hukum Positif memunculkan teori positivism hukum (legal positivism) yang meliputi Analytical legal positivism, Kelsen's Pure Theory of law dan analytical jurisprudence. John Austin, seorang ahli hukum Inggris yang menyatakan bahwa satu-satunya sumber hukum adalah kekuasaan tertinggi dalam suatu Negara. Sedangkan sumber-sumber lain hanyalah sumber yang lebih rendah. Lihat Nashriana, Loc. cit. 
menunjukkan bahwa hakim yang diminta oleh UU Pengadilan Anak kurang memahami segala hal ikhwal anak. Hakim anak seharusnya tidak begitu saja menjatuhkan pidana penjara yang didalam aturan positif Indonesia adalah sebagai upaya yang terakhir. $^{14}$

Menyangkut tentang kasus anak nakal, hakim sebaiknya lebih bijak melihat bahwa terhadap anak putusan yang diberikan semata-semata memperhatikan kepentingan yang terbaik bagi anak sebagai asas yang mendasar berlaku universal terhadap anak yang berkonflik dengan hukum karena dampak negatif pidana perampasan kemerdekaan yang dapat menghambat perkembangan fisik, psikis, dan sosial anak.

Berdasarkan data di atas menunjukkan bahwa putusan terendah yang dijatuhkan pengadilan yaitu putusan bebas, dikembalikan pada orang tua dan putusan tertinggi adalah 3 (tiga) tahun 3 bulan. Putusan terendah dijatuhkan pada tindak pidana perlindungan anak. Sedangkan putusan tertinggi dijatuhkan pada tindak pidana narkotika. Selain itu, terdapat 6 putusan yang memutuskan mengembalikan anak pada orangtuanya dan 1 putusan bebas.

Berdasarkan responden hakim, penjatuhan pidana penjara pada anak yang berkonflik dengan hukum karena dari keseluruhan kasus yang ada adalah kasus-kasus kejahatan ringan. Dari kasuskasus yang ada, tidak ada kasus yang mengadakan perdamaian antara pelaku dan korban dikarenakan kebanyakan kasus yang masuk ke Pengadilan Negeri Lhokseumawe adalah tindak pidana narkotika, pencurian, memberikan pertolongan jahat serta membujuk anak untuk melakukan cabul, sehingga hakim menjatuhkan pidana karena kejahatan tersebut adalah kejahatan yang merugikan dan meresahkan masyarakat, hakim menjatuhkan pidana penjara agar pelaku-pelaku kejahatan menjadi jera dan tidak mengulangi kejahatannya. ${ }^{15}$
Berdasarkan responden hakim, dalam waktu menangani perkara menggunakan metode yang khusus kepada anak, juga harus lebih dewasa lagi menanganinya tidak seperti perkara lain, kemudian juga sesuai dengan UU No 11 Tahun 2012 yang terakhir itu, juga dipanggil bimbingan dari pemasyarakatan untuk memberikan pendapatnya sebelum hakim memberikan keputusan, sehingga didapat kesimpulan kalau si anak itu dalam bergaul tidak terkontrol. ${ }^{16}$

Responden Hakim yang lain juga mengungkap hal yang sama dimana beliau dalam menangani kasus yang pelakunya anak keputusan atau pertimbangan yang diambil sudah barang tentu yang memperhatikan masa depan anak tersebut. ${ }^{17}$ Walaupun Putusan hakim di Pengadilan Negeri Lhoksuemawe sebagian besar adalah sanksi pidana perampasan kemerdekaan, dari pada sanksi tindakan, akan tetapi ada beberapa putusan yang dalam pertimbangan putusannya juga sudah memakai perspektif Restorative Justice karena memikirkan kepentingan si anak di masa depan.

Seperti dalam Putusan Pengadilan Nomor 130/Pid.B/2012/PN.Lsm yang diputuskan oleh Hakim Tunggal Syamsul Qamar S.H.M.H, yang diberikan kepada terdakwa:

$\begin{array}{ll}\text { Nama Lengkap } & \begin{array}{l}\text { : Muhammad Roza bin } \\ \text { Effendi }\end{array} \\ \text { Tempat Lahir/Umur } & : \text { Lhokseumawe / 14 Tahun } \\ \text { Jenis Kelamin } & : \text { Laki-Laki } \\ \text { Kebangsaan } & \text { : Indonesia } \\ \text { Tempat Tinggal } & : \text { Gg. Pisang, Lingkungan } \\ & \text { Kuta Trieng, Desa Simp. } \\ & \text { Empat Kec. Banda Sakti } \\ \text { Agama } & \text { : Islam } \\ \text { Pekerjaan } & \text { Pelajar Kelas II SMP } \\ & \text { Muhammadiyah }\end{array}$

Dalam Kasus "pencabulan terhadap anak" dalam pertimbangan hukumnya disebutkan:

\footnotetext{
Ibid

Wawancara Hakim Zulkifli, Hakim Anak di PN Lhokseumawe, 3 Juli 2015.

Wawancara dengan H. Hamzah,Hakim Anak di PN Lhokseumawe, Rabu, 25 Juni 2015.

Wawancara dengan Syamsul Qamar, Hakim Anak di PN Lhokseumawe, Tanggal 26 Juni 2015.
} 
Menimbang
: Bahwa oleh karena unsur dakwaan pertama yang didakwakan oleh jaksa Penuntut Umum atas diri terdakwa telah terpenuhi secara keseluruhan, sehingga dakwaan subsidar dipandang tidak perlu untuk dipertimbangkan lebih lanjut.

Bahwa anak adalah bagian dari generasi muda sebagai salah satu sumber daya manusia yang merupakan potensi dan penerus citacita perjuangan bangsa yang memiliki peranan strategis dan mempunyai ciri dan sifat khusus, memerlukan pembinaan dan perlindungan dalam rangka menjamin pertumbuhan dan perkembangan fisik, mental dan social secara utuh, serasi, selaras dan seimbang secara terus menerus demi kelangsungan hidup.

Bahwa terhadap penjatuhan pidana terhadap anak sejatinya hakim harus memperhatikan akan masa depan anak (terdakwa) di kemudian hari atas penjatuhan pidana. Bahwa sistem pengadilan anak diarahkan kepada penerapan keadilan khusus kepada anak yang melakukan tindak pidana dengan lebih memperhatikan perlindungan social, mental, dan moral anak dibandingkan dengan konsep pemidanaan maupun penerapan sanksi an sich.

Bahwa sebelum Hakim menjatuhkan hukuman terhadap terdakwa, Hakim lebih dahulu mempertimbangkan hal-hal yang memberatkan dan yang meringankan yang ada pada diri terdakwa sebagai berikut.
Hal-Hal yang Memberatkan terdakwa :

- $\quad$ Perbuatan terdakwa menimbulkan traumatic pada diri korban

Perbuatan terdakwa menimbulkan luka pada kemaluan korban

Korban terbilang masih belia yang tidak sepatutnya diperlakukan demikian oleh terdakwa

Hal-hal Yang Meringankan terdakwa :

- $\quad$ Terdakwa belum pernah dihukum

- Terdakwa mengakui dan mneyesali kesalahannya

Terdakwa bersikap sopan dalam persidangan Terdakwa masih berstatus pelajar kelas II SMP dan masih ingin melanjuktan sekolahnya Saran/pendapat pembimbing kemasyarakatan Menimbang :

- Bahwa dengan memperhatikan maksud tujuan penjatuhan pidana secara filosofi yang bersifat bertujuan supaya pelaku di kemudian hari (restoratif justice) menjadi seorang anak yang lebih baik dan berguna bagi masyarakat, sehingga atas dasar hal tersebut Hakim kurang sependapat dengan tuntutan Jaksa Penuntut Umum diatas.

Mengadili :

- Menyatakan terdakwa telah terbukti secara sah dan menyakinkan bersalah

Menghukum terdakwa selama 6 (enam) bulan penjara

Menetapkan pidana tersebut tidak perlu dijalankan oleh terdakwa kecuali ada perintah Hakim sebelum masa 1 (satu) tahun terdakwa melakukan tindak pidana.

Dari putusan pengadilan tersebut dapat diketahui bahwasannya hakim sudah mempertimbangkan kepentingan anak yang sedang berhadapan dengan hukum yang menurut pertimbangan hakim lebih memilih tindakan yang mengembalikan anak pada orang tuanya untuk dididik secara lebih baik, dan memilih tidak sependapat dengan Jaksa Penuntut Umum yang menuntut pidana penjara selama 9 (Sembilan) bulan dengan masa percobaan selama 1 (satu) tahun 6 (enam) bulan.

Pada Responden hakim dianggap perlu oleh hakim dipertimbangkan bahwa sanksi tersebut harus sesuai dengan kebutuhan dan masa depan anak. 
Selain itu hakim dalam memeriksa dan memutus perkara anak wajib menggali, mengikuti, dan memahami nilai-nilai yang hidup dalam masyarakat, untuk memberikan perlindungan serta mewujudkan kesejahteraan anak tetap menjaga objektifitas sehingga putusan tersebut dapat mencerminkan rasa keadilan rakyat Indonesia. ${ }^{18}$

Dari seluruh putusan yang diberikan oleh hakim adalah kebanyakan berbentuk pidana penjara dan denda, walaupun putusan yang diberikan lebih ringan dari tuntutan dalam dakwaan yang diajukan oleh jaksa penuntut umum. Adapun sebelum sampai pada putusan hakim, selayaknya seorang anak yang berkonflik dengan hukum sudah mendapat perlindungan dalam tingkat penyidikan. Penyidik wajib memeriksa tersangka anak dalam suasana kekeluargaan dan wajib meminta pertimbangan atau saran dari pembimbing kemasyarakatan. Proses penyidikan terhadap anak nakal wajib dirahasiakan. Penyidik berwenang melakukan penahanan terhadap anak yang diduga keras melakukan tindak pidana berdasarkan bukti permulaan yang cukup. Penahanan dilakukan setelah dengan sungguhsungguh mempertimbangkan kepentingan anak dan atau kepentingan masyarakat.

Hakim, penuntut umum, penyidik dan penasehat hukum, serta petugas lainnya dalam sebuah sidang anak tidak memakai toga atau pakaian dinas, meskipun petugas tidak memakai seragam tetap saja suasana sidang layaknya orang dewasa akan merupakan tekanan bagi anak, oleh karena itu seharusnya yang dijadikan ukuran adalah suasana yang nyaman bagi perkembangan kejiwaan anak. ${ }^{19}$ Pemeriksaan dilakukan tertutup dan wajib dihadiri oleh anak, orang tua, wali, atau orang tua asuhnya, penasehat hukum dan pembimbing kemasyarakatan.

Sebelum sidang dibuka hakim memerintahkan agar pembimbing kemasyarakatan menyampaikan hasil penelitian kemasyarakatan (case work) mengenai keadaan anak yang wajib dijadikan hakim sebagai bahan pertimbangan memutuskan perkara, dalam praktek hal ini tidak sepenuhnya dilakukan karena ketika Pihak kepolisian mendapat kasus anak, ada surat yang dikirimkan untuk Hakim mendapat arahan tentang kondisi anak dari Bapas, akan tetapi pihak Bapas tidak turun langsung melihat keadaan si anak yang sedang berkonflik dengan hukum tersebut. ${ }^{20}$ Hasil penelitian menunjukkan bahwa ada laporan dari pembimbing kemasyarakatan untuk 1 kasus Bapas memberikan rekomendasi ada yang berbunyi "Agar dijatuhi hukuman dan ditempatkan di penjara".

Berdasarkan hasil penelitian, diketahui bahwa dasar pertimbangan hakim dalam menjatuhkan pidana terhadap seluruh perkara anak yang ada di Pengadilan Negeri Lhokseumawe ada yang berupa pidana penjara,dan denda juga penjatuhan sanksi tindakan kepada anak nakal, dikembalikan pada orang tua, serta tidak perlu menjalankan pidana tersebut. Ada juga dengan tetap mempertimbangkan dampak positif dan negatif yang ada. Pada sanksi tindakan harusnya lebih dipertimbangkan karena orang tua atau wali terdakwa anak masih dianggap sanggup dan mampu membimbing, membina dan mendidik anaknya serta memperoleh pendidikan dan keterampilan kerja. Adapun kendala yang ditemui hakim dalam menjatuhkan putusan terhadap anak nakal antara lain:

a. Sarana dan prasarana yang terdapat di Pengadilan Negeri Lhokseumawe, guna mendukung kearah lancarnya proses persidangan belum memenuhi standar. Ruang sidang yang belum memenuhi kriteria ruang sidang anak juga tidak nyaman dalam proses persidangan. ${ }^{21}$ Hakim yang sedikit menyebabkan sidang lebih sering

Elly Sudarti, "Perlindungan Hukum Terhadap Anak Dalam Proses Ajudikasi”, Jurnal Ilmu Hukum, Vol. 2, No. 2, 2011, hlm. 14.

9 Haris Retno Susmiyati dan Hariyanti, "Sistem Peradilan Anak di Indonesia dalam Perspektif Hak Asasi Manusia”, Risalah Hukum, Juni 2007, hlm. 41.

20 Wawancara dengan Ari Sugiyono, Danru Lapas, 7 Juli 2015.

21 Dalam observasi suatu persidangan dimana anak selaku korban perkosaan ketika diminta kesaksiannya atas pidana yang dilakukan orang tua kandungnya, ditempatkan pada ruang sidang yang sama dengan ayah kandung sebagai pelakunya. 
padat.

b. Penterjemahan proses persidangan, yang sering tidak dimengerti oleh terdakwa anak.

Hadirnya Undang-Undang Nomor 35 Tahun 2014 tentang Perubahan Atas Undang-Undang Nomor 23 Tahun 2002 tentang Perlindungan Anak telah memberikan angin segar bagi perlindungan terhadap anak. Namun demikian, bukan berarti perundang-undangan ini telah menjamin dan menyelesaikan persoalan-persoalan yang dihadapi oleh anak yang berkonflik dengan hukum. Tak jarang kekerasan masih mewarnai dalam proses pemeriksaan perkara anak-anak sebagai pelaku tindak pidana, baik pada tahap penyidikan, penuntutan, maupun pada saat sidang pemeriksaan di muka pengadilan. Bahkan masih banyak anakanak yang ditempatkan dengan orang dewasa pada saat eksekusi di lembaga pemasyarakatan. ${ }^{22}$

Mengutip pendapat Muhammad Azil Maskur sedikitnya ada 5 (lima) macam pendekatan umum yang digunakan dalam menangani anak yang melakukan pelanggaran hukum, yaitu pendekatan yang murni mengedepankan kesejahteraan anak, pendekatan kesejahteraan dengan intervensi hukum, pendekatan yang menggunakan/ berpatokan pada sistem peradilan pidana semata, pendekatan edukatif dalam pemberian hukum, pendekatan penghukuman yang murni retributif. ${ }^{23}$ Pada Pengadilan Negeri Lhokseumawe seorang jaksa maupun hakim masih merangkap urusan yaitu anak dan dewasa. Hal ini dapat mengakibatkannya terbawanya kebiasaan yang dilakukan terhadap pelaku tindak pidana dewasa ke terdakwa anak.

Walau pidana penjara ini dapat dikatakan telah menjadi "pidana dunia", artinya terdapat diseluruh dunia, namun dalam perkembangannya banyak yang mempersoalkan kembali manfaat penggunaan pidana penjara sebagai salah satu sarana untuk menanggulangi masalah kejahatan yang sering dipersoalkan ialah masalah efektivitasnya.

\section{Kesimpulan}

Berdasarkan hasil penelitian dan pembahasan, yang telah disampaikan sebelumnya, maka diperoleh kesimpulan bahwa Hakim anak di Pengadilan Negeri Lhokseumawe ada yang sudah memiliki dan menerapkan prinsip restorative justice dan diversi dalam memeriksa, mengadili dan memutuskan perkara terhadap anak, yang dapat dilihat dari beberapa putusan yang memberikan keringanan hukuman dari yang dituntut oleh jaksa, bahkan ada hakim yang mengembalikan anak tersebut pada orang tuanya agar dapat dididik menjadi lebih baik.

Dalam perkembangannya di Pengadilan Negeri Lhokseumawe dapat dilihat pada awal tahun 2015 ini sudah memberikan 3 buah penetapan terhadap anak yang berkonflik dengan hukum,dimana anak tidak perlu menghadapi persidangan akan tetapi dilakukan upaya perdamaian dengan korban. Upaya tersebut adalah upaya positif untuk mendorong kearah perubahan terhadap pemidanaan anak.

Adapun beberapa bahan rekomendasi dalam rangka upaya mendorong kearah perbaikan kajian terhadap anak yang berrkonflik dengan hukum antara lain: Pertama, pada Mahkamah Agung agar melakukan pelatihan-pelatihan yang dapat meningkatkan kinerja dan keahlian seorang hakim yang mengadili perkara anak, yang diharapkan hakim tersebut lebih memiliki kepekaan terhadap kesejahteraan si anak. Kedua, Pihak kementerian Hukum dan Hak Asasi Manusia juga perlu selalu meningkatkan kinerja para pembimbing kemasyarakatan agar dapat menopang pelaksanaan tugas pembinaan anak yang berkonflik dengan hukum, termasuk juga mendidik mereka agar memahami filosopi pembinaan anak nakal.

Mahmud Mulyadi, Loc. cit.

Muhammad Azil Maskur, "Perlindungan Hukum Terhadap Anak Nakal (Juvenile Deliquency) Dalam Proses Acara Pidana Indonesia", Jurnal Pandecta, Vol. 7, No. 2, Juli 2012, hlm. 179. 


\section{DAFTAR PUSTAKA}

\section{A. Buku}

Gerungan, W.A., 1996, Psikologi Sosial, Eresco, Bandung.

Sanwani, 1997, Hak Asasi Anak Dan Perlindungan Hukum Menurut Konvensi PBB, FH. USU, Medan.

Soekanto, Soerjono dan Mamudji, Sri, 2003, Penelitian Hukum Normatif, Suatu Tinjauan Singkat, Raja Grafindo Persada, Jakarta.

\section{B. Jurnal}

Asmara, Romi, et al., "Kejahatan Kesusilaan Terhadap Anak (Suatu Tinjauan Perlindungan Hukum Terhadap Anak Perempuan Korban Kejahatan Kesusilaan Di Kota Lhokseumawe)", Jurnal Pasai, Vol. II No. 2, September 2008.

Hakim, Lukman dan Nainggolan, Masalah Perlindungan Hukum Terhadap Anak, Jurnal Equality, Vol. 10, No. 2 Agustus 2006.

Nurul, Dewi dan Musjtari, "Memberikan Hak Memilih Agama Sebagai Upaya Perlindungan Anak”, Jurnal Konstitusi, Vol. 3, No. 2, 2006.

Elly, Sudarti, "Perlindungan Hukum Terhadap Anak Dalam Proses Ajudikasi”, Jurnal Ilmu Hukum FH Unja, Vol. 2, No.2, 2011.

Saimima, Ika, P"erlindungan Terhadap Anak Yang Berkonflik Dengan Hukum", Jurnal Kajian Ilmiah Lembaga Penelitian Ubhara Jaya, Vol. 9, No. 3, 2008.

Mulyadi, Mahmud, "Perlindungan Terhadap Anak Yang Berkonflik Dengan Hukum: Upaya Menggeser Keadilan Retributif Menuju Keadilan Restoratif, Jurnal Equality, Vol. 13, No. 1, Februari 2008.

Maskur, Muhammad Azil, "Perlindungan Hukum Terhadap Anak Nakal (Juvenile eliquency)", Jurnal Pandecta, Vol. 7, No. 2, Juli 2012.

Yanuar Farida, Wimayanti, "Model Penanganan Anak Berkonflik Hukum", Jurnal Informasi, Vol. 12, No. 03, 2007.
Fauzan, "Rekonstruksi Teori Pemerataan Keadilan", Varia Peradilan, Vol. XXIII, Februari, 2008.

\section{Hasil Penelitian}

Nashriana, 2009, Pertimbangan Hakim Dalam Menjatuhkan Putusan Pidana Penjara Terhadap Anak Pelaku Penyalahgunaan Narkoba, Tesis, FH Universitas Sriwijaya, Palembang.

\section{Artikel Internet}

Sulastini, Fitriasih, "Analisa Pertimbangan Hakim Dalam Menjatuhkan Hukuman Bagi Terpidana Anak (Studi Awal Tentang Putusan Hakim Anak)", http:///lontar.ui.ac.id/opac// ui/detail.jsp, diakses tanggal 1 Maret 2015.

\section{E. Peraturan Perundang-Undangan}

Undang-Undang Nomor 11 Tahun 2012 tentang Sistem Peradilan Pidana Anak (Lembaran Negara Republik Indonesia Tahun 2012 Nomor 153, Tambahan Lembaran Negara Republik Indonesia Nomor 5332).

\section{F. Lain-Lain}

Wawancara dengan Bapak Zulkifli, Hakim Anak Di Pengadilan Negeri Lhokseumawe, Wawancara Tanggal 3 Juli 2015

Wawancara dengan Bapak H. Hamzah, Hakim Anak Di Pengadilan Negeri Lhokseumawe, Wawancara Tanggal 25 Juni 2015

Wawancara dengan Bapak Syamsul Qamar, Dahulu Hakim Anak Di Pengadilan Negeri Lhokseumawe, Wawancara Tanggal 26 Juni 2015

Wawancara dengan Bapak Ari Sugiyono, Danru Lapas Klas I Lhokseumawe, Wawancara Tanggal 7 Juni 2015. 